\title{
Effects of suprascapular and axillary nerve block on postoperative pain relief sevoflurane consumption and visual clarity in arthroscopic shoulder surgery
}

\author{
Supraskapular ve aksiller sinir bloğunun artroskopik omuz cerrahisinde \\ postoperative ağrı, sevofluran tüketimi ve görsel netliğe etkileri
}

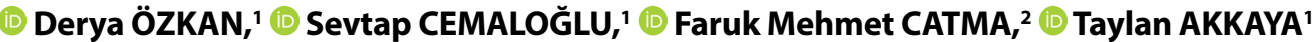

\begin{abstract}
Summary
Objectives: This study aims to investigate the effects of suprascapular nerve and axillary nerve block on postoperative pain, tramadol consumption, sevoflurane consumption and visual clarity of the surgical field in arthroscopic shoulder surgery.

Methods: Forty-six patients undergoing arthroscopic shoulder surgery were randomized to receive either both suprascapular and axillary nerve block with ultrasound guidance $(20 \mathrm{ml} 0.25 \%$ bupivacaine) before general anesthesia (group SSAXB, $\mathrm{n}=23$ ) or a subacromial local infiltration ( $20 \mathrm{ml} 0.25 \%$ bupivacaine) after the procedure (group control, $\mathrm{n}=23$ ). End-tidal sevoflurane consumption, visualization of the arthroscopic field scores of the patients were recorded during the procedure. The patient's postoperative pain scores (at PACU, 4, 8, 12, 24 hours after the surgery) and tramadol consumption were also recorded.
\end{abstract}

Results: End-tidal sevoflurane concentration values were similar in both groups ( $p>0.05$ ). Group SSAXB had a better mean static pain score in the PACU (Group SSAXB $4.27 \pm 1.48$ vs Group C $6.24 \pm 1.09 p<0.05$ ). Tramadol consumption was lower in group SSAXB than in group C $(253.1 \pm 85.3 \mathrm{mg}$ vs $324.2 \pm 72 \mathrm{mg}, \mathrm{p}=0.005)$. Visual clarity scores of the arthroscopic field were higher in group SSAXB than in group $C$ along the intraoperative period $(p<0.05)$.

Conclusion: SSAXB are effective in postoperative analgesia, reduce tramadol consumption and provide a clean image in the arthroscopic area of arthroscopic shoulder surgery, but these blocks do not reduce sevoflurane consumption.

Keywords: Axillary nerve block; shoulder arthroscopy; suprascapular nerve block.

\section{Özet}

Amaç: Bu çalışmada amaç, artroskopik omuz cerrahisinde supraskapular sinir ve aksiller sinir bloğunun postoperatif ağrı, tramadol tüketimi, sevofluran tüketimi ve cerrahi alanın görsel netliğine etkisini araştırmaktır.

Gereç ve Yöntem: Artroskopik omuz cerrahisi geçirecek 46 hasta, genel anestezi öncesi ultrason rehberliğinde hem supraskapüler hem de aksiller sinir bloğu yapılması ( $20 \mathrm{ml} \% 0.25$ bupivakain) (Grup SSAXB, $\mathrm{n}=23$ ) ya da işlem sonrası subakromiyal lokal infiltrasyon (Grup Kontrol, $n=23$ ) yapılması için randomize edildi. Hastaların soluk sonu sevofluran tüketimi, artroskopik alan görüntüsü skoru işlem sırasında kaydedildi. Hastaların postoperatif ağrı skorları (ameliyat sonrası PACU'da 4, 8, 12, 24. saat) ve tramadol tüketimi de kaydedildi.

Bulgular: Soluk sonu sevofluran konsantrasyon değerleri, her iki grupta benzerdi ( $p>0.05)$. Grup SSAXB'nin anestezi sonrası derlenme birimindeki (PACU) ortalama statik ağrı skorları daha iyiydi (Grup SSAXB 4.27 \pm 1.48 'e karşılık Grup C $6.24 \pm 1.09$ $\mathrm{p}<0.05)$. Tramadol tüketimi grup SSAXB'de grup C'den daha düşüktü ( $253.1 \pm 85.3$ mg'a karşlık $324.2 \pm 72$ mg, $p=0.005)$ Artroskopik alan netlike, görüntü skorları intraoperatif dönemde grup SSAXB'de grup C'den daha yüksekti $(p<0.05)$.

Sonuç: SSAXB artroskopik omuz cerrahisinde, postoperatif analjezide etkili, tramadol tüketimini azaltmakta ve artroskopik alanda temiz bir görüntü sağlayabilmektedir, ancak bu bloklar sevofluran tüketimini azaltmamaktadır.

'Department of Anesthesiology and Reanimation, University of Health Sciences Diskapi Yildirim Beyazit Training and Research Hospital, Ankara, Turkey ${ }^{2}$ Department of Orthopedics and Traumatology, University of Health Sciences Diskapi Yildirim Beyazit Training and Research Hospital, Ankara, Turkey Submitted (Başvuru tarihi) 28.06.2019 Accepted after revision (Düzeltme sonrası kabul tarihi) 23.09.2019 Available online date (Online yayımlanma tarihi) 13.01.2020

Correspondence: Dr. Derya Özkan. Sağılık Bilimleri Üniversitesi Dışkapı Yıldııım Beyazıt Eğitim ve Araştırma Hastanesi, Anestezi ve Reanimasyon Kliniği, Ankara, Turkey. 


\section{Introduction}

Arthroscopic shoulder surgery has been placed among routine day-case surgical methods today. However, arthroscopic shoulder surgery causes severe pain, especially in the first 48 hours. Thus, control of the pain, optimizing rehabilitation, and comfort of the postoperative patient maintained their importance. Interscalene brachial plexus block (ISB) is often preferred given that it provides postoperative analgesia in the first 6-12 hours effectively. [1] However, ISB causes 100\% hemidiaphragmatic paralysis and rebound pain in 12-20 hours after an operation, which leads to drawbacks of this block. ${ }^{[2,3]}$

Suprascapular nerve and axillary nerve are the nerves that innervate a major part of the shoulder. Therefore, the idea that sufficient postoperative analgesia can be provided in shoulder arthroscopies through concurrent blockage of two nerves (SSAXB) has arisen. ${ }^{[4]}$

Visual clarity is essential for safe and successful arthroscopic procedures. One of the methods that are used to provide safe and successful arthroscopic procedure is by lowering the blood pressure in peripheral circulation in the area, which is the surgical region. Peripheral nerve blocks cause blockage of sympathetic nerves, as well as of sensory and motor functions, and may reduce the physiological consequences of surgery-induced nociceptive transmission ${ }^{[5,6]}$ Also, sympathetic nerve block leads peripheral vasodilation and lower blood pressure in the arterial circulation, central venous system and peripheral circulation near the surgical site. ${ }^{[7]}$ Thus, SSAXB may indirectly affect visual clarity.

The primary objective of this study was to evaluate the effects of a preoperative SSAXB on postoperative pain scores and tramadol consumption in arthroscopic shoulder surgery. The secondary objective was to evaluate the efficacy of SSAXB on sevoflurane consumption and visualization of the arthroscopic area of view during the procedure.

\section{Material and Method}

This prospective, randomized study was conducted after ethics committee approval was obtained from the ethical committee of the Ministry of Health Diskapi Yildirim Beyazit Training and Research Hospital (institutional review board no: 34/01 on January 16, 2017) and written informed consent was obtained from patients.

We recruited 46 adult ASA physical status 1-2 and age between 18 and 75 years of patients scheduled for elective arthroscopic shoulder surgery under general anesthesia. Exclusion criteria included coagulopathy, neuropathy, severe cardiopulmonary disease, local anesthetic drug allergy, local site infection, body mass index greater than $35 \mathrm{~kg} / \mathrm{m}^{2}$, severe diabetes mellitus, inability to understand pain scores. Patients were randomly assigned using a computer-generated list of numbers, to either both suprascapular and axillary nerve block with ultrasound guidance, before general anesthesia (group SSAXB, $n=23$ ) or a subacromial local infiltration after the procedure (group C, $n=23$ ). Intravenous access and ECG (Electrocardiography), pulse oximeter, noninvasive blood pressure, BIS (bispectral index) monitoring was applied for all patients.

For SSAXB, a Sonosite M turbo (Sonosite, Bothell, Washington) with a high frequency (15-6 MHz) linear probe was used. Patients were placed in the lateral decubitus position. Using dual guidance, an $80 \mathrm{~mm}$ stimulator needle Echoplex ${ }^{\circledast}$ (Vygon, Ecouen, France) was advanced with the in-plain technique according to the described technique for suprascapulary block. ${ }^{[8]}$ After observing the stimulation of the supraspinatus and/or infraspinatus muscle, local anesthetic (10 $\mathrm{ml} 0.25 \%$ bupivacaine) was injected in the supraspinatus fossa. For the axillary nerve block, the ultrasound transducer was placed in a sagittal plane over the humeral head on the posterior aspect of the arm to identify the deltoid muscle, neck of the humerus, the teres minor muscle, the circumflex humeral artery, and the triceps muscle. After the neurovascular quadrangular space identification and observing the deltoid muscle response to stimulation, a local anesthetic (10 $\mathrm{ml} 0.25 \%$ bupivacaine) was injected with the in-plain technique. ${ }^{[9]}$ Thirty minutes after local anesthetic infiltration, a blinded observer evaluated the level of block. Motor block external shoulder rotation and shoulder abduction with arm 90 degrees (for suprascapular nerve), shoulder abduction (for axillary nerve) were assessed with a 4-point Medical Research Council scale. ${ }^{[10]}$ Sensory block was assessed with cold sensation 4-point numeric scale $(0=$ 
no cold sensation, $1=$ strongly reduced cold sensation, $3=$ lightly reduced cold sensation, $4=$ normal cold sensation). The sensory block of this nerve was not tested since the suprascapular nerve carries no cutaneous afferent fibers. ${ }^{[11]}$

In all patients, general anesthesia was induced with propofol, remifentanil, and rocuronium. After endotracheal intubation, anesthesia was maintained with a mixture of air and sevoflurane in oxygen and remifentanil $0.05 \mathrm{mcg} / \mathrm{kg} / \mathrm{min}$. The end-tidal $\mathrm{CO}_{2}$ and the endtidal sevoflurane concentrations were continuously measured in the breathing cycle with a pre-calibrated gas monitor (Scio Four Oxy plus Medibus Fabius GS; Drager Medical, Lubeck, Germany). The patients were ventilated so that the end-tidal carbon dioxide value would be $35-45 \mathrm{mmHg}$ following endotracheal intubation. The sevoflurane concentration was adjusted according to the BIS value of between 40 and 60 . In both groups, the surgeon administered irrigation fluid through a standard posterior portal $(0.33 \mathrm{mg}$ epinephrine mixed to $1 \mathrm{~L}$ saline) during the procedure.

In group C, the surgeon administered $20 \mathrm{ml}$ of $0.25 \%$ bupivacaine to the subacromial region at the end of the procedure. To prevent a rapid effusion of the solution, the injection was performed after skin closure and through a different site from portals used during arthroscopy.

All patients received ondansetron $(4 \mathrm{mg}$ ) for nausea prophylaxis and dexketoprofen $50 \mathrm{mg}$ iv at the end of the surgery. Postoperative analgesia (tramadol bolus $20 \mathrm{mg}$, lock-out time $10 \mathrm{~min}$ ) was initiated with intravenous PCA for $24 \mathrm{~h}$.

Hemodynamic changes, BIS values, end-tidal sevoflurane consumption, visual clarity scores (VC) $(0$ to 10 , with 10 correspondings to the best visual clarity possible) of the arthroscopic field of the patients were recorded every five minutes by an observer who blinded to the technique during the procedure. VC scores of $<4$ was defined as "poor," "fair" when $4<$ VC $<7$, and "good" when VC $>7^{[12]}$ (Fig. 1). Patient's postoperative pain scores (NRS 0 to 10, with 10 corresponding to worst pain) were recorded in the postanesthesia care unit (PACU), two hours (T2), four hours (T4), eight hours (T8), 12 hours (T12) and 24 hours (T24) after surgery. Tramadol consumption

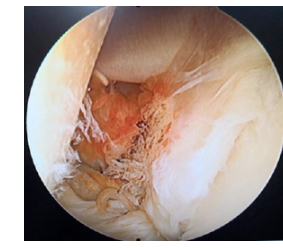

Good

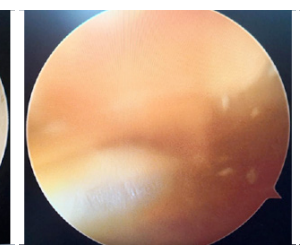

Fair
Poor

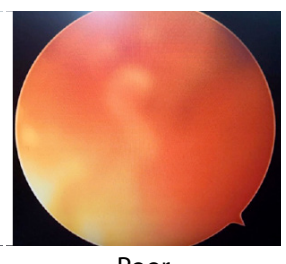

Figure 1. Quality of visibility was scored using the Visual clarity score (VC). ${ }^{[12]}$ It was categorized as 'good' when NRS is more than 7 , 'fair' when VC is between 4 and 7 and 'poor' when VC is less than 4. All three images in the picture were obtained through optical lenses established with the posterior portal. All these three images show the rotator interval (Stryker Endoscopy 5900 Optical Court San Jose, CA USA).

was also recorded. Hence, the patients were immobilized in a sling; dynamic pain scores could not be obtained properly. Nausea, vomiting and complications related to blocks (e.g., arterial puncture, hematoma, paresthesia during injection) were recorded. Follow-ups in the PACU and ward were carried out by an anesthetist blinded to the treatment group.

The power analysis was performed before this study, according to a pilot study. Twenty-one cases were planned for each group to test the statistical significance of at least $30 \%$ difference of NRS levels from the baseline between two groups at PACU monitoring time on the $90 \%$ power and $5 \%$ error level. Anticipating the dropout rate, 46 patients were included in this study.

Data analysis was performed on the SPSS package program (Statistical Package for Social Science Inc., Chicago, IL, USA) for Windows. The Kolmogorov-Smirnov test was used to determine whether the distribution of continuous and intermittent numerical variables was close to normal, and the homogeneity of variances was investigated by Levene's test. Descriptive statistics were expressed as mean \pm standard deviation or median (minimum-maximum) for the continuous and intermittent numerical variables and the nominal variables as case numbers and percentages. The nominal variables were examined using Pearson's chisquare and Fisher's exact tests. ANOVA in repeated measures was used to assess whether there was a statistically significant change in hemodynamic measurements in the groups according to the monitoring time. When the results were significant, the corrected Bonferroni multiple comparison or Wilcoxon Sign test was used to determine the follow-up durations that caused the difference. A $p$-value of $<0.05$ was considered statistically significant. 


\section{Results}

Forty-three patients completed this study (Fig. 2). Two patients in group $C$ (due to conversion to open surgery) and one patient in group SSAXB (due to vasovagal response) were lost to follow up. Patients demographic details were similar ( $p>0.05$ ) (Table 1). The incidence of the incomplete block at 30 minutes in Group SSAXB is shown in Table 2. In the SSAXB group, 80 to $90 \%$ of the patients had complete blocks in the related territories.

During the procedure between the two groups, MAP and HR values were comparable $(p>0.05)$. The end- tidal sevoflurane concentration and BIS values were similar in both groups at all time points ( $p>0.05)$ (Fig. 3). Visual clarity scores of the arthroscopic field were higher in group SSAXB than in group $C$ along the intraoperative period $(p<0.05)$ (Fig. 4). Group SSAXB had a better mean static pain score in the PACU (Group SSAXB 4.27 \pm 1.48 vs Group C $6.24 \pm 1.09$ $\mathrm{p}<0.05)$ (Fig. 5). Tramadol consumption was lower in group SSAXB than in group C $(253.1 \pm 85.3 \mathrm{mg}$ vs $324.2 \pm 72 \mathrm{mg}, \mathrm{p}=0.005$ ) (Table 1). In the PACU, two patients in the $C$ group experienced nausea versus one patient in the SSAXB group. There was no complication related to the blocks in patients.

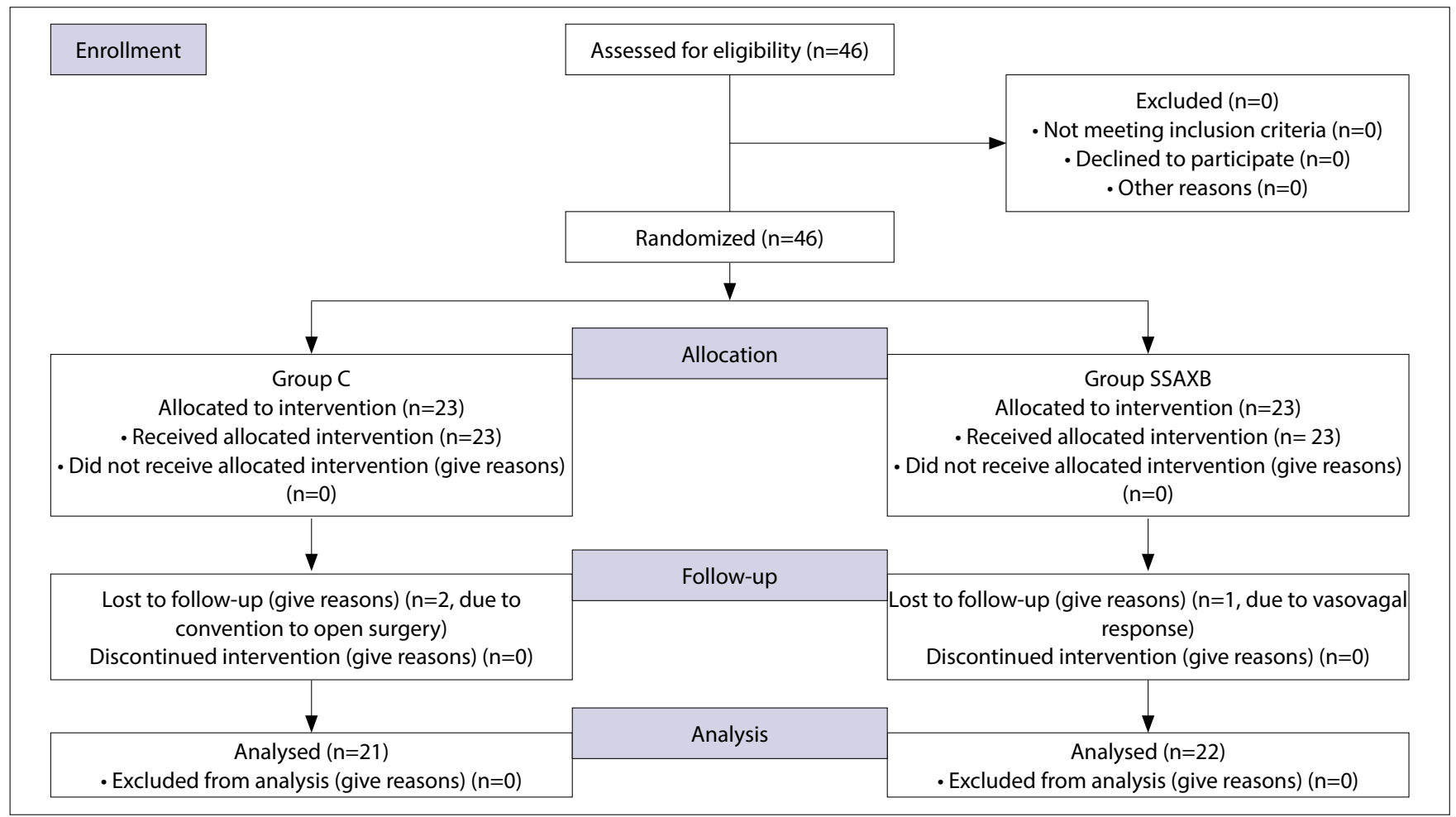

Figure 2. C, control (subacromial) group; SSAXB, suprascapular-axillary nerve block group.

Table 1. Perioperative details of the patients. Data are presented as mean \pm SD or number of patients (\%)

\begin{tabular}{lccc}
\hline & Group C (n=21) & Group SSAXB (n=22) & p \\
\hline Age $(\mathrm{yr})($ mean $\pm \mathrm{SD})$ & $53.7 \pm 16.5$ & $58.5 \pm 7.9$ & $>0.05$ \\
Sex $(\mathrm{F} / \mathrm{M}) \mathrm{n}(\%)$ & $11 / 10(52 / 48)$ & $15 / 7(68 / 32)$ & $>0.05$ \\
BMI $\left(\mathrm{kg} / \mathrm{m}^{2}\right)($ mean $\pm \mathrm{SD})$ & $28.7 \pm 3.6$ & $28.6 \pm 5.7$ & $>0.05$ \\
Surgical Procedure $\mathrm{n}(\%)$ & & & $7(77)$ \\
Rotator cuff repair & $17(81)$ & $2(9)$ & $>0.05$ \\
Bankart repair & $4(19)$ & $3(14)$ & $>0.05$ \\
Decompression & 0 & $253.1 \pm 85.3$ & $>0.05$ \\
Total opioid consumption $(\mathrm{mg} / 24 \mathrm{~h})($ mean $\pm \mathrm{SD})$ & $324.2 \pm 72$ & $0.005^{*}$ \\
\hline
\end{tabular}

${ }^{*} \mathrm{p}<0.05$ significant differences between the groups. 
Table 2. Incidence of incomplete Block at 30 minutes in Group SSAXB data are presented as number of patients (\%)

\begin{tabular}{lccc}
\hline & Sensory & Motor & p \\
\hline $\begin{array}{l}\text { Suprascapular n } \\
\text { (supraspinatus m), n (\%) }\end{array}$ & - & $3(13)$ & N/A \\
$\begin{array}{l}\text { Suprascapular } \mathrm{n} \\
\text { (infraspinatus m), n (\%) }\end{array}$ & - & $3(13)$ & N/A \\
Axillary n (deltoid m), n (\%) & $2(9)$ & $4(18)$ & $>0.05$ \\
\hline
\end{tabular}
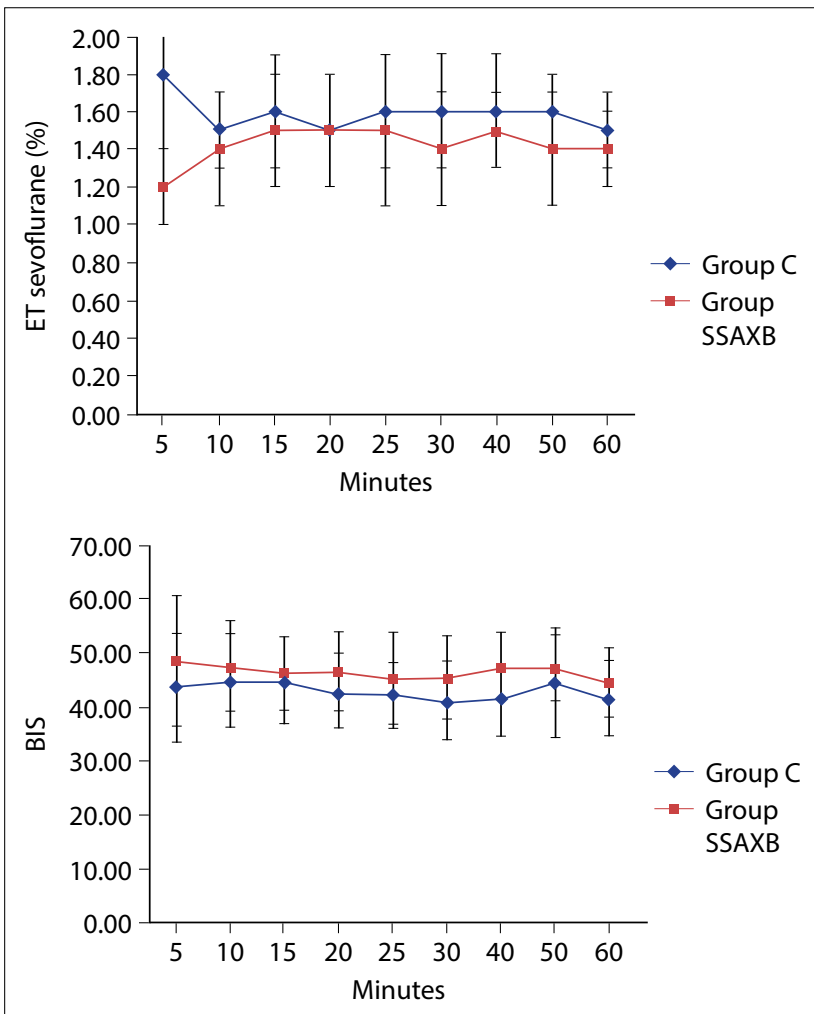

Figure 3. Changes in BIS values and ET sevoflurane concentrations of the patients. Data are expressed as mean \pm SD ( $p>0.05$ at all time points).

\section{Discussion}

SSAXB caused lower pain scores and consumption of less opioids than the control group throughout postoperative 24 hours in this study. SSAXB provided better visual clarity than the control (subacromial block) group in the intraoperative period.

ISB provides excellent analgesia within the first six postoperative hours in shoulder surgery. However, it poses a risk, especially for patients with lung pathology because it leads to $100 \%$ ipsilateral phrenic nerve block (hemidiaphragmatic paralysis) and causes rebound pain. ${ }^{[2]}$ The other undesired effect of ISB is that it leads to sensory and motor block in lower

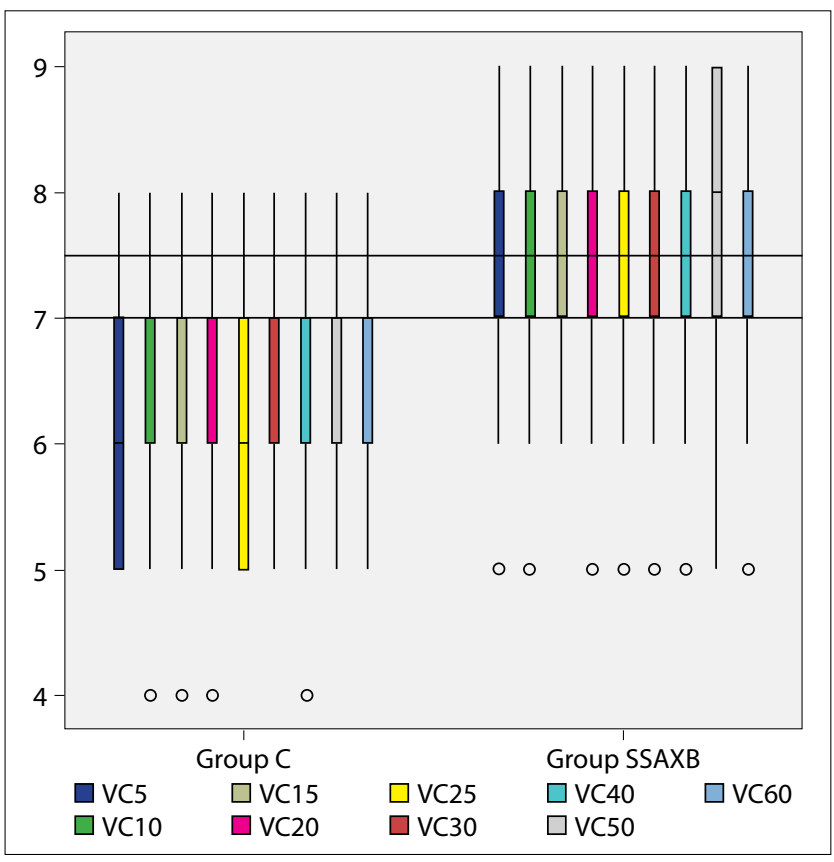

Figure 4. The visual clarity scores of the patients in the $5^{\text {th }}, 10^{\text {th }}$, $15^{\text {th }}, 20^{\text {th }}, 30^{\text {th }}, 40^{\text {th }}, 50^{\text {th }}, 60^{\text {th }}$ minutes after the surgery starts are recorded as VC5, VC10,VC15, VC20, VC30, VC40, VC50, VC60, respectively. Data are presented as the median and interquartile range (IQR), open circles slight outliers, $\mathrm{p}<0.005$ at all-time points.

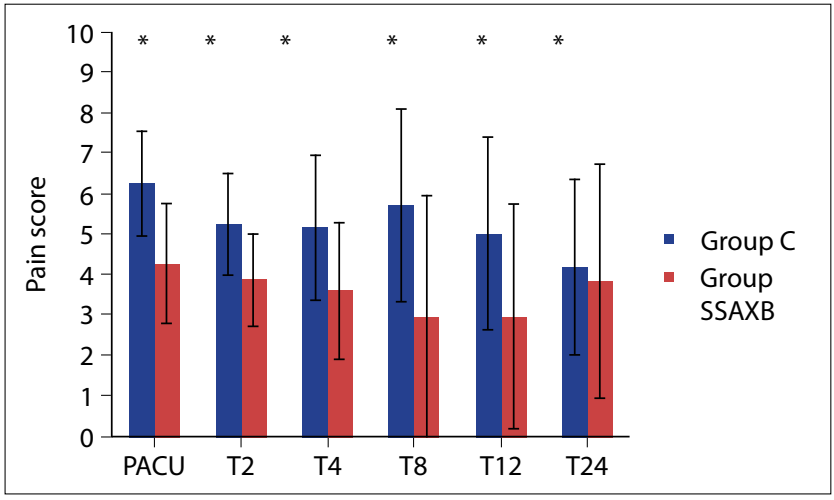

Figure 5.Pain scores after surgery. Data are expressed as mean \pm SD $\left({ }^{*} p<0.05\right)$.

brachial plexus (C7-T1) aside from the shoulder area on which surgical operation will be implemented. ${ }^{[13]}$ Even if it is thought that the undesired effects of ISB could be prevented through applying low local anesthetic concentration ( $0.125 \%$ bupivacaine) and its volumes $(5-10 \mathrm{~mL})$, it was found out that the risk to patients had not been wiped out. ${ }^{[14,15]}$ All these situations provide excellent analgesia within the first postoperative hours in shoulder surgeries, but they cause drawbacks in ISB implementation. Safer multimodal analgesia techniques may be more logical to be implemented instead of ISB. SSAXB, which will be used for this purpose, maybe a part of the multimodal analgesia concept.

Shoulder joint is innervated by several peripheral 
nerves that originate from both lateral and posterior cord. ${ }^{[16]}$ Suprascapular and axillary nerve constitute a major part of this innervation, but the blockage of these two nerves may not be sufficient for complete anesthesia to occur in shoulder surgery. ${ }^{[17]}$ However, it is reported that suprascapular block provides better control of postoperative pain and patient's satisfaction than intraarticular or subacromial injection and increases the range of movement. ${ }^{[18,19]}$ ISB provides more efficient analgesia than SSAXB in the immediate postoperative period, but SSAXB provides better control of pain in 24 hours in a study where SSAXB and ISB in arthroscopic shoulder surgery are compared. ${ }^{[20]}$ Similarly, Neuts et al'.s ${ }^{[21]}$ study revealed that SSAXB provides effective analgesia just as ISB in postoperative 24 hours in shoulder arthroscopy. Dyspnea and discomfort in the ISB group were found out more than the SSAXB group in patients within the same study. All patients also used NSAID, paracetamol and opioid PCA for postoperative analgesia in both studies. Better pain scores and lower consumption of tramadol in the SSAXB group than the control group were obtained in this study as it had been expected.

Inhalation anesthetics, which are intraoperatively used to assess the anesthetic-analgesic effectiveness of nerve blocks or evaluation of opioid consumption may be a good indicator. ${ }^{[22]}$ However, that the findings showed that SSAXB did not cause a decrease in sevoflurane consumption in comparison with the control group contrary to expectations in this study. The reason for this situation may be explained as, that the concentration of sevoflurane was adjusted according to the level of BIS 40-60 anesthesia. Mean BIS values were $40-50$ trends in this study in both groups. These levels of BIS values were lower than we expected before. Thus, sufficient analgesia may have been provided in the level of BIS 40-50 anesthesia also in the control group.

Given that intraarticular bleeding may damage the visual clarity in shoulder arthroscopies, a bloodless view is aimed at the surgical site. Plenty of techniques, such as electrocautery, pumps which control the speed and pressure of irrigation fluid, vasoconstrictors, which are added into the irrigation fluid while hypotensive anesthesia is used to optimize the clear view in the surgical site. ${ }^{[12]}$ However, these methods may not be sufficient alone and also cause negative effects. For example, cerebral perfusion may be more damaged on the beach-chair position where especially shoulder arthroscopy is performed when hypotensive anesthesia is applied. ${ }^{[12]}$ The application of excessive pump pressure may cause extravasation of irrigation fluid on soft tissue. ${ }^{[23]}$ Despite epinephrine, which is added into irrigation fluid, visual clarity may still be impaired. ${ }^{[23]}$ Epinephrine was added into the irrigation fluid in both groups for the visual clarity, but hypotensive anesthesia and the excessive pump was not used in this study.

It is reported that both peripheral and central blocks lead to sympathectomy with resultant peripheral vasodilation and lower blood pressure in the arterial circulation, central venous system and peripheral circulation near the surgical site. ${ }^{[5,7]}$ Malik et al. ${ }^{[24]}$ emphasize the regional anesthesia techniques reduce bleeding during surgery when compared with general anesthesia. A recent study also indicates that preoperative ISB can improve visual clarity for the arthroscopic procedure. ${ }^{[25]}$ In another clinical report, when a singlesided erector spinae plane block is performed for lumbar spine surgery, it is noted that there is no need for hypotensive techniques as a block providing satisfactory sympathetic blockade and regional vasodilation with a clear surgical field in the block. ${ }^{[26]}$ These studies confirm our hypothesis. Better visual clarity was acquired in the group where SSAXB was conducted in the surgical site than the control group.

There are some limitations to this study. First, the patient could not be blinded to the technique. However, since all patients' shoulder was covered with wrap, the assessor which utilized postoperative pain assessment was blind. Second, since the visual clarity was not the primary outcome, a power analysis was performed based on postoperative tramadol consumption. Therefore, future studies are needed to assess the visual clarity related to SSAXB.

In conclusion, SSAXB is effective in postoperative analgesia, reduce tramadol consumption in 24 hours, but does not reduce sevoflurane consumption. SSAXB may provide a clean image in the arthroscopic area for arthroscopic shoulder surgery.

Ethical Approval: Ethical committee of University of Health Sciences Diskapi Yildirim Beyazit Training and Research Hospital (34/01 on January 16, 2017).

Conflict-of-interest issues regarding the authorship or article: None declared.

Peer-rewiew: Externally peer-reviewed. 


\section{References}

1. Abdallah FW, Halpern SH, Aoyama K, Brull R. Will the real benefits of single-shot interscalene block please stand up? A systematic review and meta-analysis. Anesth Analg 2015;120(5):1114-29. [CrossRef]

2. Salinas FV, Joseph RS. Peripheral nerve blocks for ambulatory surgery. Anesthesiol Clin 2014;32(2):341-55. [CrossRef]

3. Bergmann L, Martini S, Kesselmeier M, Armbruster W, Notheisen T, Adamzik M, et al. Phrenic nerve block caused by interscalene brachial plexus block: breathing effects of different sites of injection. BMC Anesthesio. 2016;16(1):45.

4. Price DJ. The shoulder block: a new alternative to interscalene brachial plexus blockade for the control of postoperative shoulder pain. Anaesth Intensive Care 2007;35(4):575-81.

5. Sørensen J, Bengtsson M, Malmqvist EL, Nilsson G, Sjöberg F. Laser Doppler perfusion imager (LDPI) - for the assessment of skin blood flow changes following sympathetic blocks. Acta Anaesthesiol Scand 1996;40(9):1145-8.

6. Dahl JB, Møiniche S. Pre-emptive analgesia. Br Med Bull 2004;71:13-27. [CrossRef]

7. Modig J. Regional anaesthesia and blood loss. Acta Anaesthesiol Scand Suppl 1988;89:44-8. [CrossRef]

8. Harmon D, Hearty C. Ultrasound guided suprascapular nerve block technique. Pain Physician 2007;10(6):743-6.

9. Rothe C, Asghar S, Andersen HL, Christensen JK, Lange $\mathrm{KH}$. Ultrasound guided block of the axillary nerve: a volunteer study of a new method. Acta Anaesthesiol Scand 2011;55(5):565-70. [CrossRef]

10. Vanhoutte EK1, Faber CG, van Nes SI, Jacobs BC, van Doorn $\mathrm{PA}$, van Koningsveld $\mathrm{R}$, et al; PeriNomS Study Group. Modifying the Medical Research Council grading system through Rasch analyses. Brain 2012;135(Pt 5):1639-49.

11. Ajmani ML. The cutaneous branch of the human suprascapular nerve. J Anat 1994;185( Pt 2):439-42.

12. van Montfoort DO, van Kampen PM2, Huijsmans PE. Epinephrine Diluted Saline Irrigation Fluid in Arthroscopic Shoulder Surgery: A Significant Improvement of Clarity of Visual Field and Shortening of Total Operation Time. A Randomized Controlled Trial. Arthroscopy 2016;32(3):436-44.

13. Shin HJ, Na HS, Oh AY, Hwang JW, Kim BG, Park HP, et al. A prospective, randomized and controlled study of interscalene brachial plexus block for arthroscopic shoulder surgery: A comparison of C5 and conventional approach, a CONSORT-compliant article. Medicine (Baltimore) 2016;95(37):e4921. [CrossRef]

14. Krone SC, Chan VW, Regan J, Peng P, Poate EM, McCartney $C$, et al. Analgesic effects of low-dose ropivacaine for interscalene brachial plexus block for outpatient shoulder surgery-a dose-finding study. Reg Anesth Pain Med 2001;26(5):439-43. [CrossRef]
15. Lee JH, Cho SH, Kim SH, Chae WS, Jin HC, Lee JS, et al. Ropivacaine for ultrasound-guided interscalene block: $5 \mathrm{~mL}$ provides similar analgesia but less phrenic nerve paralysis than $10 \mathrm{~mL}$. Can J Anaesth 2011;58(11):1001-6. [CrossRef]

16. Aszmann OC, Dellon AL, Birely BT, McFarland EG. Innervation of the human shoulder joint and its implications for surgery. Clin Orthop Relat Res 1996;(330):202-7. [CrossRef]

17. Tran DQ, Elgueta MF, Aliste J, Finlayson RJ. DiaphragmSparing Nerve Blocks for Shoulder Surgery. Reg Anesth Pain Med 2017;42(1):32-8. [CrossRef]

18. Jeske HC1, Kralinger F, Wambacher M, Perwanger F, Schoepf $\mathrm{R}$, Oberladstaetter J, et al. A randomized study of the effectiveness of suprascapular nerve block in patient satisfaction and outcome after arthroscopic subacromial decompression. Arthroscopy 2011;27(10):1323-8. [CrossRef]

19. Singelyn FJ, Lhotel L, Fabre B. Pain relief after arthroscopic shoulder surgery: a comparison of intraarticular analgesia, suprascapular nerve block, and interscalene brachial plexus block. Anesth Analg 2004;99(2):589-92. [CrossRef]

20. Dhir S, Sondekoppam RV, Sharma R, Ganapathy S, Athwal GS. A Comparison of Combined Suprascapular and Axillary Nerve Blocks to Interscalene Nerve Block for Analgesia in Arthroscopic Shoulder Surgery: An Equivalence Study. Reg Anesth Pain Med 2016;41(5):564-71. [CrossRef]

21. Neuts A, Stessel B, Wouters PF, Dierickx C, Cools W, Ory $J P$, et al. Selective Suprascapular and Axillary Nerve Block Versus Interscalene Plexus Block for Pain Control After Arthroscopic Shoulder Surgery: A Noninferiority Randomized Parallel-Controlled Clinical Trial. Reg Anesth Pain Med 2018;43(7):738-44. [CrossRef]

22. Karaman T, Ozsoy AZ, Karaman S, Dogru S, Tapar H, Sahin A, et al. The effects of transversus abdominis plane block on analgesic and anesthetic consumption during total abdominal hysterectomy: a randomized controlled study. [Article in Portuguese] Rev Bras Anestesiol 2018;68(3):285-91. [CrossRef]

23. Hsiao MS, Kusnezov N, Sieg RN, Owens BD, Herzog JP. Use of an Irrigation Pump System in Arthroscopic Procedures. Orthopedics. 2016;39(3):e474-8. [CrossRef]

24. Malik O, Brovman EY, Urman RD. The Use of Regional or Neuraxial Anesthesia for Below-Knee Amputations May Reduce the Need for Perioperative Blood Transfusions. Reg Anesth Pain Med. 2018;43(1):25-35. [CrossRef]

25. Choi S, Kim T, Kwon YS, Kang H. Intra-operative effect of interscalene brachial plexus block to arthroscopic rotator cuff repair surgery. Int Orthop 2019;43(9):2117-24. [CrossRef]

26. Brandão J, Graça R, Sá M, Cardoso JM, Caramelo S, Correia C. Lumbar erector spinae plane block: Successful control of acute pain after lumbar spine surgery - A clinical report. [Article in English, Spanish] Rev Esp Anestesiol Reanim 2019;66(3):167-71. [CrossRef] 